\title{
The inclusion of functional foods enriched in fibre, calcium, iodine, fat-soluble vitamins and $n-3$ fatty acids in a conventional diet improves the nutrient profile according to the Spanish reference intake
}

\author{
Izaskun Berasategi ${ }^{1}$, Marta Cuervo ${ }^{1}$, Arantza Ruiz de las Heras ${ }^{2}$, Susana Santiago ${ }^{1}$, \\ J Alfredo Martínez ${ }^{1}$, Iciar Astiasarán ${ }^{1}$ and Diana Ansorena ${ }^{1, *}$ \\ ${ }^{1}$ Faculty of Pharmacy, Department of Nutrition and Food Sciences, Physiology and Toxicology, University of \\ Navarra, Irunlarrea s/n, 31008 -Pamplona, Navarra, Spain: ${ }^{2}$ Servicio de Alimentación Clínica y Dietética, \\ Hospital Virgen del Camino, Pamplona, Navarra, Spain
}

Submitted 6 March 2010: Accepted 9 September 2010: First published online 19 November 2010

\begin{abstract}
Objective: The growing interest in maintaining good health status through optimal nutrition has boosted the launch of a number of functional foods on the market. The objective of the present study was to theoretically evaluate the nutritional relevance of incorporating selected enriched foods in the diet.

Design: A $28 \mathrm{~d}$ dietary plan, designed to be balanced under the recommended macronutrients criteria, was used as a basal diet. Some conventional foods were exchanged with foods enriched in fibre, calcium, iodine, vitamins A, D, E or $n-3$ fatty acids.

Setting: Nutritional composition of basal and modified diets was derived and compared to the Spanish recommended intakes (RI)

Results: The basal diet covered the recommendations for fibre and calcium with mean intake of $28 \mathrm{~g}$ and $1241 \mathrm{mg}$, respectively. The current intake of salt, if iodized, or bread elaborated with this salt, allowed reaching the daily intake of iodine every day, with a mean supply of $216 \mu \mathrm{g} / \mathrm{d}$ and $278 \mu \mathrm{g} / \mathrm{d}$, respectively. The deficient supply of vitamin $\mathrm{E}$ in the basal diet (mean $=8 \mathrm{mg} / \mathrm{d}$ ) was covered by including enriched margarine and dairy products (mean $=15 \mathrm{mg} / \mathrm{d}$ ). The low $n-3$ fatty acids intake in the basal diet $(1 \cdot 1 \mathrm{~g} / \mathrm{d})$ increased up to $1.9 \mathrm{~g} / \mathrm{d}$ after the use of enriched margarine, butter and biscuits and soya drink instead of milk.

Conclusions: In order to improve the accomplishment of the RI iodine, vitamin $\mathrm{E}$ and $n-3$ fatty acids, interesting strategies dealing with the incorporation of enriched foods in the diet were successfully initiated.
\end{abstract}

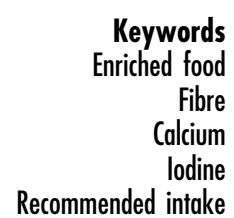

Keywords

Fibre

lodine

Recommended intake
Consumers are concerned about the impact of nutrition on well-being and health. This fact has given rise to the development of new food products, with new formulations designed to increase the supply of some compounds with healthy biological activities and even others whose functionality has been proved only more recently.

Functional foods can be considered to be those whole, fortified, enriched or enhanced foods that provide health benefits beyond the provision of essential nutrients (e.g. vitamins and minerals) when they are consumed at efficacious levels as part of a varied diet on a regular basis ${ }^{(1)}$. Functional foods represent one of the most intensively investigated and widely promoted areas in the food and nutrition sciences nowadays.

There is scientific evidence proving that the intake of numerous essential and non-essential dietary components influences growth, development and performance as well as disease prevention ${ }^{(2)}$.

There is a great offer of functional foods and especially of enriched foods on the market. However, there are not many studies showing the real impact of these foods in the diet and the extent to which they really assure an efficient supply of the required compounds in a diet.

Fibre, calcium, iodine, vitamins $\mathrm{A}, \mathrm{D}$ and $\mathrm{E}$ and $n-3$ fatty acids are essential compounds that are often used to develop enriched foods as a consequence of their demonstrated functionality. Fibre is considered an efficient protective agent for a wide variety of illnesses, including CVD, colon cancer and constipation ${ }^{(3,4)}$.

Iodine is considered an essential nutrient in relation to the synthesis of thyroid hormones and for thyroid function, in addition to being important for brain development. 
Indeed, iodine deficiency is well known and the use of iodized salt has been established by WHO in trying to reduce it $^{(5)}$.

The relationship between calcium and bone metabolism is well known, as is the importance of an adequate intake (AI) of calcium as a key factor in decreasing the risk of osteoporosis $^{(6)}$. Vitamin D is directly related to the metabolic efficiency of calcium, its intake being necessary for the utilization of calcium by the organism ${ }^{(7)}$. Vitamin A, whose important physiological function in normal functioning was known earlier, has also been shown to be an interesting antioxidant, being implicated in anti-carcinogenesis as well as in immunological and anti-degenerative processes through several investigations ${ }^{(8)}$. Vitamin $\mathrm{E}$ has also been shown in different epidemiological studies to have a potent antioxidative function ${ }^{(9,10)}$.

The need for an optimal $n-3$ fatty acids intake and the reduced amounts recommended with regard to the essential linolenic fatty acid have been studied in the last several years. The beneficial effects of a low $n-6: n-3$ ratio in relation to the prevention and development of CVD have been widely investigated ${ }^{(11)}$. The European Union has established legal criteria for fibre, vitamins and minerals and recently for $n$ - 3 fatty acids in order to make nutritional claims on commercial foods ${ }^{(12,13)}$.

The objective of the present study was to evaluate the nutritional relevance of incorporating some foods enriched in different nutrients in a basal diet. A total or partial substitution of some conventional foods by their enriched counterparts was assayed.

\section{Materials and methods}

The basal diet was based on a $28 \mathrm{~d}$ dietary plan, which was designed by expert dietitians and nutritionists in order to provide the nutritional needs of a reference adult $^{(14)}$. The mean value for the energy supply was $9904 \mathrm{~kJ} / \mathrm{d}(2367 \mathrm{kcal} / \mathrm{d})$, of which $52 \cdot 4 \%$ was supplied by carbohydrates, $28.4 \%$ was supplied by fat, and protein contributed $18.7 \%$ of the total energy requirement.

\section{Enriched foods}

Enriched foods containing increased amounts of fibre, calcium, iodine, vitamins $\mathrm{A}, \mathrm{D}$ and $\mathrm{E}$ and $n$-3 were selected from the market. Table 1 shows the nutritional composition of these foods (obtained from the nutritional labels) and that of their corresponding conventional foods (obtained from food composition tables).

\section{Modified diets}

Enriched foods were used as substitutes for their respective conventional counterparts in the newly developed special diets (diets 1-12). Table 2 shows the thirteen types of diet (basal and modified diets) designed according to the nutrient supply and the nutritional information of the foods exchanged in the different proposed diets.
With regard to fibre enrichment, several special diets were designed with different enriched foods. In diet 1 , cereals (bread, breakfast cereals and biscuits) were substituted by whole cereals; in diet 2, dairy products (milk and yoghurt) were substituted by their fibre-enriched versions; in diet 3, both cereals and dairy products were changed. For calcium and vitamins A, D and E, only one alternative diet was proposed in each case, including foods found on the market that increased each compound (diets 4, 8, 9 and 10, respectively). For iodine, the developed diets followed different criteria because of the difficulty in finding iodine-enriched products. In Spain, iodization of salt is not obligatory, but iodine is allowed to be added at $60 \mathrm{mg} / \mathrm{kg}$ salt ${ }^{(15)}$. The information given by WHO regarding the recommended total daily salt intake $(5 \mathrm{~g})$, the estimated total daily mean salt intake ( $11 \mathrm{~g})$ and the percentage of table salt referred to the total mean salt intake (13\%) was taken into account in developing the different diets ${ }^{(5)}$. Therefore, diet 5 was elaborated by substituting $0.65 \mathrm{~g}$ ( $13 \%$ of $5 \mathrm{~g}$ ) of table salt with iodized salt and diet 6 , by substituting $1.5 \mathrm{~g}$ ( $13 \%$ of $11 \mathrm{~g}$ ) of the total salt with iodized salt. Finally, diet 7 was developed by substituting the bread included in the basal diet (180 g/d) with bread made with iodized salt.

For $n$ - 3 fatty acids, two diets were proposed to increase the supply of these nutrients. Both of them substituted the conventional margarine, butter and biscuits of the basal diet with their corresponding enriched alternatives. Moreover, these diets included the substitution of milk with n-3-enriched milk (diet 11) or with soya drink (diet 12).

Trained dietitians derived the energy and nutrient intake of the $28 \mathrm{~d}$ dietary plan from Spanish food composition tables, using a computer program (Calidiet, University of Navarra, Spain). Values of $n-3$ and $n-6$ fatty acids were taken directly from food composition tables ${ }^{(16)}$. Derivation was made before and after the substitution of diets by the enriched foods. All data were compared to the recommended intake (RI) or AI of energy and nutrients for the Spanish adult population ${ }^{(16)}$.

\section{Data analysis}

Statistical analysis was performed using the Statistical Package for the Social Sciences statistical software package version $15 \cdot 0$ (SPSS Inc., Chicago, IL, USA). Data presented are mean, SD, median, interquartile range (25th and 75 th percentiles), minimum and maximum. Normal distribution was analysed with the Kolmogorov-Smirnov tests. Nonparametric tests (Friedman and Wilcoxon) were used to compare data obtained from the different substitutions on each compound.

\section{Results and discussion}

Regulation (EC) No 1924/2006 of the European Parliament and of the Council of 20 December 2006 on the 
Table 1 Nutritional information of selected enriched foods (1) and their conventional counterparts (2)

\begin{tabular}{|c|c|c|c|c|c|c|c|c|c|c|c|}
\hline Food & $\mathrm{kJ}$ & kcal & $\begin{array}{l}\text { Protein } \\
\text { (g) }\end{array}$ & $\begin{array}{l}\text { Lipoprotein } \\
\text { (g) }\end{array}$ & $\begin{array}{l}\text { PUFA } \\
\text { (g) }\end{array}$ & $\begin{array}{l}\text { Fibre } \\
\text { (g) }\end{array}$ & $\begin{array}{c}\mathrm{Ca} \\
(\mathrm{mg})\end{array}$ & $\begin{array}{l}\text { lodine } \\
(\mu \mathrm{g})\end{array}$ & $\begin{array}{l}\text { Vitamin } A \\
(\mu \mathrm{g})\end{array}$ & $\begin{array}{l}\text { Vitamin D } \\
(\mu \mathrm{g})\end{array}$ & $\begin{array}{l}\text { Vitamin } E \\
(\mathrm{mg})\end{array}$ \\
\hline \multicolumn{12}{|l|}{ Products used for fibre substitution } \\
\hline Skimmed yoghurt with fibre (1) & 176 & 42 & $4 \cdot 3$ & 0.2 & $0 \cdot 10$ & $4 \cdot 8$ & 131 & - & - & - & - \\
\hline Yoghurt (2) & 138 & 33 & $4 \cdot 0$ & $0 \cdot 1$ & - & - & 133 & - & 0.09 & - & - \\
\hline Wholemeal breakfast cereals (1) & 1105 & 264 & $10 \cdot 4$ & $2 \cdot 8$ & - & $32 \cdot 1$ & 350 & - & - & - & - \\
\hline Breakfast cereals (2) & 1452 & 347 & $7 \cdot 0$ & 0.8 & $0 \cdot 30$ & $2 \cdot 5$ & 15 & 10 & 0.00 & $2 \cdot 10$ & $0 \cdot 40$ \\
\hline Toasted whole bread (1) & 1544 & 369 & $12 \cdot 0$ & 8.5 & - & $11 \cdot 0$ & - & - & - & - & - \\
\hline Toasted bread (2) & 1188 & 285 & $10 \cdot 1$ & $2 \cdot 5$ & 1.00 & 4.5 & 85 & 7 & 0.00 & 0.00 & 0.01 \\
\hline Sandwich wholemeal bread (1) & 1117 & 267 & $10 \cdot 8$ & $3 \cdot 1$ & $0 \cdot 80$ & $7 \cdot 1$ & - & - & - & - & - \\
\hline Sandwich bread (2) & 1067 & 255 & $5 \cdot 52$ & $3 \cdot 74$ & $1 \cdot 14$ & $4 \cdot 54$ & 22 & - & $3 \cdot 51$ & - & $0 \cdot 21$ \\
\hline Whole bread (1) & 1008 & 241 & $8 \cdot 0$ & $1 \cdot 4$ & - & $8 \cdot 5$ & 21 & 1 & - & - & $0 \cdot 20$ \\
\hline Bread (2) & 1017 & 244 & $9 \cdot 0$ & $1 \cdot 6$ & 0.34 & 3.5 & 56 & 4 & 0.00 & 0.00 & Tr. \\
\hline Whole biscuits (1) & 1728 & 413 & $7 \cdot 8$ & $21 \cdot 0$ & - & $23 \cdot 0$ & - & - & - & - & - \\
\hline Biscuits (2) & 1925 & 460 & $7 \cdot 5$ & $19 \cdot 0$ & $2 \cdot 50$ & $3 \cdot 1$ & 118 & 28 & Tr. & $2 \cdot 20$ & $2 \cdot 30$ \\
\hline Semi-skimmed milk with fibre (1) & 222 & 53 & $3 \cdot 1$ & 1.55 & - & $4 \cdot 0$ & 120 & - & $120 \cdot 00$ & 0.75 & 1.50 \\
\hline Semi-skimmed milk (2) & 184 & 45 & 3.5 & $1 \cdot 6$ & Tr. & 0.0 & 125 & 9 & $18 \cdot 90$ & 0.02 & 0.04 \\
\hline \multicolumn{12}{|l|}{ Products used for vitamins A, D and E substitution } \\
\hline Skimmed yoghurt with vitamins $A$ and $D(1)$ & 151 & 36 & $4 \cdot 0$ & $0 \cdot 1$ & - & $0 \cdot 0$ & 130 & - & $120 \cdot 00$ & 0.75 & - \\
\hline Skimmed yoghurt (2) & 138 & 33 & $4 \cdot 0$ & $0 \cdot 1$ & - & - & 133 & - & 0.09 & - & - \\
\hline $\begin{array}{l}\text { Semi-skimmed milk with proteins, } \mathrm{Ca} \text {, vitamins } \mathrm{A}, \mathrm{D} \text {, } \\
\mathrm{E} \text { and } \mathrm{B}_{9}(1)\end{array}$ & 205 & 49 & 3.9 & 1.5 & - & - & 160 & - & $120 \cdot 00$ & 0.75 & $1 \cdot 50$ \\
\hline Semi-skimmed milk (2) & 184 & 45 & $3 \cdot 5$ & $1 \cdot 6$ & Tr. & $0 \cdot 0$ & 125 & 9 & $18 \cdot 90$ & 0.02 & 0.04 \\
\hline Margarine with $\mathrm{Ca}$, milk, vitamins $\mathrm{A}, \mathrm{D}$ and $\mathrm{E}(1)$ & 2276 & 544 & 0.4 & $60 \cdot 0$ & $14 \cdot 00$ & 0.0 & 120 & - & $800 \cdot 00$ & $7 \cdot 50$ & $20 \cdot 00$ \\
\hline Margarine (2) & 3050 & 729 & 0.8 & $80 \cdot 4$ & $31 \cdot 20$ & 0.0 & 27 & - & $799 \cdot 00$ & $7 \cdot 94$ & $8 \cdot 00$ \\
\hline \multicolumn{12}{|l|}{ Products used for Ca substitution } \\
\hline Semi-skimmed milk with $\mathrm{Ca}$ and vitamin $\mathrm{D}(1)$ & 234 & 56 & $4 \cdot 3$ & 1.55 & - & - & 160 & - & $120 \cdot 00$ & $0 \cdot 80$ & 1.50 \\
\hline Semi-slimmed milk (2) & 184 & 45 & 3.5 & $1 \cdot 6$ & Tr. & 0.0 & 125 & 9 & $18 \cdot 90$ & 0.02 & 0.04 \\
\hline Yoghurt with $\mathrm{Ca}$ and vitamin D (1) & 326 & 78 & $3 \cdot 3$ & $1 \cdot 4$ & - & 0.0 & 120 & - & - & 0.75 & - \\
\hline Yoghurt (2) & 444 & 106 & 3.5 & $2 \cdot 7$ & $0 \cdot 10$ & Tr. & 130 & 48 & $22 \cdot 00$ & 0.04 & 0.08 \\
\hline \multicolumn{12}{|l|}{ Products used for iodine substitution } \\
\hline lodized salt (1) & - & - & - & - & - & - & 29 & 6000 & - & - & - \\
\hline Salt (2) & - & - & - & - & - & - & 29 & 44 & - & - & - \\
\hline Bread made with iodized salt (1) & 1138 & 272 & $7 \cdot 8$ & $1 \cdot 0$ & - & $2 \cdot 2$ & 19 & 93 & - & - & - \\
\hline Bread (2) & 1017 & 244 & $9 \cdot 0$ & $1 \cdot 6$ & 0.34 & 3.5 & 56 & 4 & 0.00 & 0.00 & Tr. \\
\hline \multicolumn{12}{|l|}{ Products used for $n-3$ substitution } \\
\hline Margarine with $n-3$ and $n-6$ (1) & 1360 & 325 & 0.1 & $35 \cdot 0$ & $n-3: n-6=3 \cdot 5 / 15 \cdot 0$ & - & - & - & - & - & - \\
\hline Margarine (2) & 3050 & 729 & 0.8 & $80 \cdot 4$ & $\begin{array}{c}31 \cdot 20 \\
n-3: n-6=1 \cdot 5 / 36 \cdot 1\end{array}$ & 0.0 & 27 & - & $799 \cdot 00$ & $7 \cdot 94$ & $8 \cdot 00$ \\
\hline Butter with soya oil (1) & 1506 & 360 & 0.0 & $39 \cdot 0$ & $n-3: n-6=1 \cdot 5 / 14 \cdot 5$ & 0.23 & - & - & - & - & - \\
\hline Butter (2) & 3138 & 750 & 0.6 & $83 \cdot 0$ & $\begin{aligned} 2 \cdot 07 \\
n-3: n-6=0 \cdot 4 / 1 \cdot 8\end{aligned}$ & 0.0 & 15 & 0 & $828 \cdot 00$ & 0.76 & $2 \cdot 00$ \\
\hline Biscuits with $n-3$ (1) & 1983 & 474 & $7 \cdot 0$ & $20 \cdot 3$ & $n-3=300 \mathrm{mg}$ & $2 \cdot 9$ & - & - & - & - & - \\
\hline Biscuits (2) & 1925 & 460 & $7 \cdot 5$ & $19 \cdot 0$ & $\begin{aligned} & 2 \cdot 50 \\
n-3: n-6 & =0 \cdot 17 / 2 \cdot 23\end{aligned}$ & $3 \cdot 1$ & 118 & 28 & Tr. & $2 \cdot 20$ & $2 \cdot 30$ \\
\hline Milk with $\mathrm{Ca}, \mathrm{P}, n-3$, DHA, vitamins $\mathrm{B}, \mathrm{A}$ and $\mathrm{E}(1)$ & 289 & 69 & $3 \cdot 0$ & $3 \cdot 0$ & 1.50 & $0 \cdot 0$ & 140 & - & $120 \cdot 00$ & 0.75 & $1 \cdot 50$ \\
\hline Milk (2) & 184 & 45 & 3.5 & $1 \cdot 6$ & $\begin{array}{c}0.03 \\
n-3: n-6=0.008 / 0.025\end{array}$ & 0.0 & 125 & 9 & $18 \cdot 90$ & 0.02 & 0.04 \\
\hline Soya drink (1) & 276 & 66 & $3 \cdot 0$ & $1 \cdot 7$ & 1.04 & 0.5 & 120 & - & $120 \cdot 00$ & 0.75 & - \\
\hline Milk (2) & 184 & 45 & 3.5 & $1 \cdot 6$ & $\begin{array}{c}0.03 \\
n-3: n-6=0.008 / 0 \cdot 025\end{array}$ & $0 \cdot 0$ & 125 & 9 & $18 \cdot 90$ & 0.02 & 0.04 \\
\hline
\end{tabular}


Table 2 Thirteen types of diet depending on the foods that have been chosen to be exchanged by their enriched counterparts

\begin{tabular}{|c|c|c|c|}
\hline Nutrients & Diet & Conventional food & Enriched food \\
\hline Fibre $(\mathrm{Al}=25 \mathrm{~g})$ & $\begin{array}{l}0 \\
1 \\
2 \\
3\end{array}$ & $\begin{array}{l}\text { Basal diet } \\
\text { Cereals } \\
\text { Dairy products } \\
\text { Cereals plus dairy products }\end{array}$ & $\begin{array}{l}\text { Whole cereals } \\
\text { Dairy products enriched in fibre } \\
\text { Whole cereals plus dairy products enriched in fibre }\end{array}$ \\
\hline $\mathrm{Ca}(\mathrm{RI}(>20$ years $)=800 \mathrm{mg})$ & $\begin{array}{l}0 \\
4\end{array}$ & $\begin{array}{l}\text { Basal diet } \\
\text { Dairy products }\end{array}$ & Dairy products enriched in $\mathrm{Ca}$ \\
\hline $\begin{array}{l}\text { lodine }(R \mathrm{R}>20 \text { years: } \text { men }=140 \mu \mathrm{g} \\
\quad \text { women }=100 \mu \mathrm{g})\end{array}$ & $\begin{array}{l}0 \\
5 \\
6 \\
7\end{array}$ & $\begin{array}{l}\text { Basal diet } \\
0.65 \mathrm{~g} \text { table salt addition } \\
1.5 \mathrm{~g} \text { table salt addition } \\
\text { Conventional bread }\end{array}$ & $\begin{array}{l}0.65 \mathrm{~g} \text { iodized table salt addition } \\
1.5 \mathrm{~g} \text { iodized table salt addition } \\
\text { Bread elaborated with iodized salt }\end{array}$ \\
\hline $\begin{array}{l}\text { Vitamin } \mathrm{A}(\mathrm{RI}>20 \text { years: } \mathrm{men}=1000 \mu \mathrm{g} \\
\quad \text { women }=800 \mu \mathrm{g})\end{array}$ & $\begin{array}{l}0 \\
8\end{array}$ & $\begin{array}{l}\text { Basal diet } \\
\text { Dairy products and margarine }\end{array}$ & Vitamin A-enriched dairy products and margarine \\
\hline Vitamin $D(R I=5 \mu \mathrm{g})$ & $\begin{array}{l}0 \\
9\end{array}$ & $\begin{array}{l}\text { Basal diet } \\
\text { Dairy products and margarine }\end{array}$ & Vitamin D-enriched dairy products and margarine \\
\hline Vitamin $E(R I=12 \mu \mathrm{g})$ & $\begin{array}{r}0 \\
10\end{array}$ & $\begin{array}{l}\text { Basal diet } \\
\text { Dairy products and margarine }\end{array}$ & Vitamin E-enriched dairy products and margarine \\
\hline$n-3$ fatty acids $(\mathrm{RI}=1 \cdot 3 \mathrm{~g})$ & $\begin{array}{r}0 \\
11 \\
12\end{array}$ & $\begin{array}{l}\text { Basal diet } \\
\text { Margarine, butter, milk and } \\
\text { biscuits } \\
\text { Margarine, butter, milk and } \\
\text { biscuits }\end{array}$ & $\begin{array}{l}\text { Margarine, butter, milk and biscuits enriched in } \\
n-3 \text { fatty acids } \\
\text { Margarine, butter, soya drink and biscuits } \\
\text { enriched in } n-3 \text { fatty acids }\end{array}$ \\
\hline
\end{tabular}

Al, adequate intake; RI, recommended intake according to the Spanish recommended values for adults.

Diet 0 is the basal diet and diets $1-12$ introduce several modifications, depending on the nutrient.

nutrition and health claims made on foods pointed out that a varied and balanced diet is a prerequisite for good health, having products that have a relative importance in the context of the total diet. Thus, it is interesting to evaluate the diets in a global context to conclude about their suitability in relation to generally accepted nutritional recommendations.

The present study aimed at following a theoretical approach to the intake of enriched foods, based on data obtained from food composition tables and from labels of the foods included in the study. However, the different bioavailability of nutrients was not taken into account. Table 2 shows the nutritional composition of the enriched foods used for the substitutions. It can be observed that, in general, except for the component in which the modified food is enriched, the composition of these products can be considered equivalent to that of conventional foods. Only one exception deserves a comment: modified margarine and butter showed a significantly lower amount of fat than did conventional products.

Table 3 shows the mean amounts of the different nutrients for the basal and modified diets during the $28 \mathrm{~d}$ of the dietary plan. Other descriptive parameters are also included (SD, median, percentiles (25th and 75th), minimum and maximum). Table 4 shows the descriptive parameters with regard to the percentages of the RI or AI for each nutrient covered by the different diets.

With regard to fibre intake, a mean value of $28 \mathrm{~g} / \mathrm{d}$ was observed for the basal diet, higher than $25 \mathrm{~g}$, which was taken as the AI (Table 3). On a daily basis, $76 \%$ of the days achieved the AI (Table 4). The day with the minimum supply reached $75 \cdot 1 \%$ of the AI.

In the Dorica II Study, mean fibre consumption was $21 \mathrm{~g} / \mathrm{d}$ in men and $18 \mathrm{~g} / \mathrm{d}$ in women ${ }^{(17)}$. Another study carried out on thirty-eight postmenopausal women aged between 46 and 60 years showed that this population consumed $21.3 \mathrm{~g}$ fibre/ $\mathrm{d}^{(18)}$. The results obtained in another study carried out on children gave similar values $(19 \cdot 4 \mathrm{~g} / \mathrm{d})^{(19)}$. Castetbon et al $^{(20)}$ estimated that the daily mean intake of fibre in France is $19 \cdot 1 \mathrm{~g} / \mathrm{d}$ in men and $15.9 \mathrm{~g} / \mathrm{d}$ in women, similar to the intake in Spain. The Seguimiento Universidad de Navarra (SUN) cohort study revealed intakes of fibre in Spanish university graduates to be around $26.7 \mathrm{~g} / \mathrm{d}$, an amount similar to that observed in the present study. In this cohort, fibre from cereals was statistically significantly associated with a reduction in the risk of hypertension, with wholegrain bread being the main source of this type of fibre ${ }^{(21)}$.

When foods enriched in fibre (cereals, dairy products and a combination of both) were included in the diet instead of their respective conventional products, significant increases of fibre were detected every day, with amounts over the RI. In some cases, it was even possible to observe that the intake could be extremely high. Diet 3 (including enriched cereals and dairy products) reached a mean value of $66 \mathrm{~g} / \mathrm{d}$ with a range of $51 \cdot 2-78.8 \mathrm{~g} / \mathrm{d}$, which means $204-315 \%$ of the RI. It has to be noted that there are studies pointing out that an excessive intake of fibre can cause adverse effects. The consumption of high amounts of dietary fibre may cause a decrease in the 
Table 3 Descriptive statistics obtained for the amounts of the different nutrients in the different diets

\begin{tabular}{|c|c|c|c|c|c|c|c|c|}
\hline \multirow[b]{2}{*}{ Nutrient } & \multirow[b]{2}{*}{ Diet } & \multirow[b]{2}{*}{ Mean } & \multirow[b]{2}{*}{ SD } & \multirow[b]{2}{*}{ Median } & \multicolumn{2}{|c|}{ Percentiles } & \multirow[b]{2}{*}{ Minimum } & \multirow[b]{2}{*}{ Maximum } \\
\hline & & & & & 25th & 75th & & \\
\hline \multirow{4}{*}{ Fibre $(g / d)$} & 0 & 28 & 5 & $26 \cdot 9^{a}$ & $25 \cdot 1$ & $32 \cdot 0$ & $18 \cdot 8$ & $40 \cdot 7$ \\
\hline & 1 & 46 & 6 & $45 \cdot 2^{b}$ & $41 \cdot 7$ & $49 \cdot 0$ & $35 \cdot 4$ & $57 \cdot 0$ \\
\hline & 2 & 48 & 7 & $48 \cdot 7^{c}$ & 41.9 & $52 \cdot 1$ & $34 \cdot 3$ & $60 \cdot 1$ \\
\hline & 3 & 66 & 8 & $66 \cdot 9^{d}$ & $58 \cdot 5$ & $71 \cdot 4$ & $51 \cdot 2$ & $78 \cdot 8$ \\
\hline \multirow{2}{*}{$\mathrm{Ca}(\mathrm{mg} / \mathrm{d})$} & 0 & 1241 & 162 & $1206 \cdot 9^{a}$ & $1118 \cdot 7$ & $1372 \cdot 4$ & $985 \cdot 4$ & $1561 \cdot 9$ \\
\hline & 4 & 1394 & 178 & $1363 \cdot 9^{b}$ & $1268 \cdot 2$ & $1504 \cdot 9$ & $1055 \cdot 4$ & $1766 \cdot 1$ \\
\hline \multirow[t]{4}{*}{ lodine $(\mu \mathrm{g} / \mathrm{d})$} & 0 & 128 & 55 & $107 \cdot 7^{\mathrm{a}}$ & $100 \cdot 3$ & $142 \cdot 7$ & $72 \cdot 4$ & $366 \cdot 2$ \\
\hline & 5 & 166 & 55 & $146 \cdot 7^{b}$ & $138 \cdot 4$ & $181 \cdot 7$ & $111 \cdot 4$ & $405 \cdot 2$ \\
\hline & 6 & 216 & 55 & $196 \cdot 8^{\mathrm{c}}$ & $190 \cdot 3$ & $230 \cdot 4$ & $162 \cdot 4$ & $456 \cdot 2$ \\
\hline & 7 & 278 & 63 & $272 \cdot 4^{d}$ & $246 \cdot 2$ & $307 \cdot 0$ & $158 \cdot 0$ & $526 \cdot 4$ \\
\hline \multirow[t]{2}{*}{ Vitamin A $(\mu \mathrm{g} / \mathrm{d})$} & 0 & 1039 & 539 & $978 \cdot 3^{a}$ & $694 \cdot 4$ & $1291 \cdot 8$ & $309 \cdot 8$ & $2772 \cdot 1$ \\
\hline & 8 & 1506 & 633 & $1426 \cdot 4^{b}$ & $1197 \cdot 8$ & $1724 \cdot 9$ & $141 \cdot 1$ & $3341 \cdot 5$ \\
\hline \multirow[t]{2}{*}{ Vitamin D $(\mu \mathrm{g} / \mathrm{d})$} & 0 & 6 & 8 & $2 \cdot 9^{\mathrm{a}}$ & 0.9 & $8 \cdot 7$ & 0.1 & $30 \cdot 9$ \\
\hline & 9 & 10 & 8 & $6 \cdot 7^{\mathrm{b}}$ & $4 \cdot 4$ & $12 \cdot 6$ & $1 \cdot 6$ & $33 \cdot 4$ \\
\hline \multirow[t]{2}{*}{ Vitamin $E(m g / d)$} & 0 & 8 & 2 & $8 \cdot 0^{\mathrm{a}}$ & $5 \cdot 9$ & $9 \cdot 3$ & $4 \cdot 2$ & $12 \cdot 1$ \\
\hline & 10 & 15 & 3 & $15 \cdot 2^{b}$ & $12 \cdot 5$ & $17 \cdot 8$ & $10 \cdot 6$ & $19 \cdot 8$ \\
\hline \multirow[t]{3}{*}{$n-3$ Fatty acids $(\mathrm{g} / \mathrm{d})$} & 0 & $1 \cdot 1$ & 0.7 & $0.9^{a}$ & 0.78 & 1.35 & 0.3 & $4 \cdot 3$ \\
\hline & 11 & $1 \cdot 4$ & $0 \cdot 7$ & $1 \cdot 2^{b}$ & $1 \cdot 00$ & $1 \cdot 58$ & $0 \cdot 6$ & $4 \cdot 4$ \\
\hline & 12 & 1.9 & $0 \cdot 7$ & $1 \cdot 8^{\mathrm{C}}$ & $1 \cdot 51$ & $2 \cdot 16$ & $1 \cdot 1$ & 4.9 \\
\hline
\end{tabular}

Results include the mean value, SD, the median, the 25 th and 75 th percentiles and the minimum and maximum values for the $28 \mathrm{~d}$.

Mean values within a column with unlike superscript letters were significantly different among diets within each nutrient $(P<0 \cdot 05)$.

Table 4 Descriptive statistics obtained for the percentages of RI or Al covered by the different diets

\begin{tabular}{|c|c|c|c|c|c|c|c|c|c|}
\hline \multirow[b]{2}{*}{ Nutrient } & \multirow[b]{2}{*}{ Diet } & \multirow[b]{2}{*}{ Mean } & \multirow[b]{2}{*}{ SD } & \multirow[b]{2}{*}{ Median } & \multicolumn{2}{|c|}{ Percentiles } & \multirow[b]{2}{*}{ Minimum } & \multirow[b]{2}{*}{ Maximum } & \multirow{2}{*}{$\begin{array}{l}\% \text { of days in } \\
\text { which daily } \\
\text { intake is covered }\end{array}$} \\
\hline & & & & & 25th & 75th & & & \\
\hline \multirow[t]{4}{*}{ Fibre $(\mathrm{Al}=25 \mathrm{~g})$} & 0 & 111 & 21 & $107 \cdot 5^{a}$ & $100 \cdot 5$ & $128 \cdot 2$ & $75 \cdot 1$ & $162 \cdot 9$ & 76 \\
\hline & 1 & 183 & 22 & $180 \cdot 9^{b}$ & $166 \cdot 6$ & $195 \cdot 8$ & $141 \cdot 7$ & $227 \cdot 8$ & 100 \\
\hline & 2 & 192 & 27 & $194 \cdot 8^{\mathrm{C}}$ & $167 \cdot 5$ & $208 \cdot 5$ & $137 \cdot 4$ & $240 \cdot 5$ & 100 \\
\hline & 3 & 264 & 31 & $267 \cdot 6^{\mathrm{d}}$ & $234 \cdot 0$ & $285 \cdot 4$ & $204 \cdot 9$ & $315 \cdot 2$ & 100 \\
\hline \multirow[t]{2}{*}{$\mathrm{Ca}(\mathrm{RI}=800 \mathrm{mg})$} & 0 & 155 & 20 & $151 \cdot 0^{\mathrm{a}}$ & $140 \cdot 0$ & $171 \cdot 6$ & $123 \cdot 2$ & $195 \cdot 2$ & 100 \\
\hline & 4 & 174 & 22 & $170 \cdot 5^{b}$ & $158 \cdot 5$ & $188 \cdot 1$ & $131 \cdot 9$ & $220 \cdot 8$ & 100 \\
\hline \multicolumn{10}{|l|}{ lodine } \\
\hline \multirow[t]{4}{*}{ Men $(R I=140 \mu \mathrm{g})$} & 0 & 91 & 39 & $76 \cdot 9^{a}$ & $71 \cdot 7$ & $101 \cdot 9$ & $51 \cdot 7$ & $261 \cdot 6$ & 25 \\
\hline & 5 & 119 & 39 & $104 \cdot 8^{\mathrm{b}}$ & $98 \cdot 2$ & $129 \cdot 8$ & $79 \cdot 5$ & $289 \cdot 4$ & 71 \\
\hline & 6 & 155 & 39 & $140 \cdot 5^{\mathrm{c}}$ & $136 \cdot 0$ & $164 \cdot 6$ & $116 \cdot 0$ & $325 \cdot 8$ & 100 \\
\hline & 7 & 199 & 45 & $194 \cdot 5^{\mathrm{d}}$ & $175 \cdot 8$ & $219 \cdot 3$ & $112 \cdot 8$ & $376 \cdot 0$ & 100 \\
\hline \multirow[t]{4}{*}{ Women $(R \mathrm{I}=110 \mu \mathrm{g})$} & 0 & 116 & 50 & $97 \cdot 9^{a}$ & $91 \cdot 2$ & $129 \cdot 7$ & $65 \cdot 8$ & 332.9 & 46 \\
\hline & 5 & 151 & 50 & $133 \cdot 4^{\mathrm{b}}$ & $125 \cdot 8$ & $165 \cdot 2$ & $101 \cdot 2$ & 368.6 & 100 \\
\hline & 6 & 197 & 50 & $178 \cdot 9^{c}$ & $173 \cdot 0$ & $209 \cdot 4$ & $147 \cdot 6$ & $414 \cdot 7$ & 100 \\
\hline & 7 & 253 & 57 & $247 \cdot 6^{d}$ & $223 \cdot 8$ & $279 \cdot 1$ & $143 \cdot 6$ & $478 \cdot 5$ & 100 \\
\hline \multicolumn{10}{|l|}{ Vitamin A } \\
\hline \multirow[t]{2}{*}{ Men $(\mathrm{RI}=1000 \mu \mathrm{g})$} & 0 & 104 & 54 & $97 \cdot 8^{a}$ & $69 \cdot 4$ & $129 \cdot 2$ & $31 \cdot 0$ & $277 \cdot 2$ & 46 \\
\hline & 8 & 150 & 63 & $142 \cdot 6^{\mathrm{b}}$ & $119 \cdot 8$ & $172 \cdot 5$ & $14 \cdot 1$ & $334 \cdot 2$ & 86 \\
\hline \multirow[t]{2}{*}{ Women $(\mathrm{RI}=800 \mu \mathrm{g})$} & 0 & 130 & 67 & $122 \cdot 3^{a}$ & $86 \cdot 8$ & $161 \cdot 5$ & $38 \cdot 7$ & $346 \cdot 5$ & 57 \\
\hline & 8 & 188 & 79 & $178 \cdot 3^{\mathrm{b}}$ & $149 \cdot 7$ & $215 \cdot 6$ & $17 \cdot 6$ & $417 \cdot 7$ & 93 \\
\hline \multirow[t]{2}{*}{ Vitamin $\mathrm{D}(\mathrm{RI}=5 \mu \mathrm{g})$} & 0 & 122 & 165 & $58 \cdot 1^{a}$ & $18 \cdot 5$ & $174 \cdot 3$ & $1 \cdot 8$ & $618 \cdot 0$ & 36 \\
\hline & 9 & 196 & 164 & $133 \cdot 7^{\mathrm{b}}$ & 88.5 & $252 \cdot 6$ & $31 \cdot 0$ & $599 \cdot 4$ & 68 \\
\hline \multirow[t]{2}{*}{ Vitamin $E(R I=12 \mathrm{mg})$} & 0 & 65 & 19 & $66 \cdot 5^{\mathrm{a}}$ & $49 \cdot 6$ & $77 \cdot 5$ & $34 \cdot 8$ & $100 \cdot 7$ & 36 \\
\hline & 10 & 124 & 25 & $126 \cdot 6^{\mathrm{b}}$ & $104 \cdot 5$ & $148 \cdot 3$ & $88 \cdot 6$ & $164 \cdot 8$ & 82 \\
\hline \multirow{3}{*}{$n-3(\mathrm{RI}=1 \cdot 3 \mathrm{~g})$} & 0 & 86 & 56 & $71 \cdot 2^{a}$ & $59 \cdot 8$ & $104 \cdot 1$ & $26 \cdot 4$ & $327 \cdot 9$ & 25 \\
\hline & 11 & 107 & 54 & $89 \cdot 8^{\mathrm{b}}$ & $77 \cdot 4$ & $121 \cdot 7$ & $46 \cdot 8$ & $336 \cdot 9$ & 43 \\
\hline & 12 & 149 & 55 & $138 \cdot 0^{c}$ & $116 \cdot 6$ & $166 \cdot 0$ & $81 \cdot 1$ & $376 \cdot 1$ & 93 \\
\hline
\end{tabular}

Results include the mean value, the standard deviation, the median, the 25 th and 75 th percentiles and the minimum and maximum values for the $28 \mathrm{~d}$. $\mathrm{RI}$, recommended intake; Al, adequate intake.

Mean values within a column with unlike superscript letters were significantly different among diets within each nutrient $(P<0 \cdot 05)$.

absorption of minerals such as iron, calcium and zinc ${ }^{(22)}$. Excessive fibre consumption can also cause an increase in gastrointestinal motility, flatulence, nausea, etc. ${ }^{(23)}$. Moreover, Escudero and Gonzalez ${ }^{(24)}$ confirmed some cases of intestinal obstruction and formation of phytobezoars with the ingestion of a high amount of non-fermentable fibre, especially when water intake is limited.

Dairy products are an important constituent of food in preventing osteoporosis, as they are the major source of dietary calcium ${ }^{(25)}$, and are hence important for the effects 
of calcium on bone ${ }^{(26)}$. The daily requirement for calcium is set at $800 \mathrm{mg}$, which was always achieved in the basal diet, as the minimum calcium intake was $985.4 \mathrm{mg}$. The mean value for the basal diet was $1241 \mathrm{mg} / \mathrm{d}$, whereas $1394 \mathrm{mg} / \mathrm{d}$ ( $174 \%$ of the RI) was reached when using calcium-fortified foods (Tables 3 and 4). These data agree with data reported by $\mathrm{WHO}^{(27)}$, in which calcium intake by adults in Spain is $1267 \mathrm{mg} / \mathrm{d}$, and with data from the SUN cohort ${ }^{(28)}$.

However, other studies have revealed dietary calcium insufficiencies. The calcium intake of Spanish university students was below the recommendations, between $650 \mathrm{mg} / \mathrm{d}$ and $750 \mathrm{mg} / \mathrm{d}$, and it was lower in women ${ }^{(29)}$. However, calcium consumption of elderly people was $792 \mathrm{mg} / \mathrm{d}$ for women and $813 \mathrm{mg} / \mathrm{d}$ for men ${ }^{(30)}$.

In a study carried out with Irish adults, it was observed that the mean calcium intake of this population was $805 \mathrm{mg} / \mathrm{d}$ for men and $938 \mathrm{mg} / \mathrm{d}$ for women. It was also observed that $66 \%$ of individuals (65\% of men and $68 \%$ of women) consumed fortified foods ${ }^{(31)}$. Calcium intake in France was $974 \mathrm{mg} / \mathrm{d}$ in men and $837 \mathrm{mg} / \mathrm{d}$ in women $^{(20)}$. The results show that with the designed basal diets there is no need to include calcium-fortified foods to cover current recommendations. The use of enriched foods such as dairy products significantly increased the amounts of calcium in the diet, reaching amounts much higher than the RI. It has been proved that a high intake of calcium has deleterious effects on health, as it is associated with prostate cancer ${ }^{(32)}$. Zinc absorption can also be reduced, as a result of interactive effects with the intestine $^{(33)}$. Nevertheless, the highest amount of calcium found in the present study corresponded to that in diet 4, reaching a maximum of $1766 \mu \mathrm{g} / \mathrm{d}$, still far from the UL (upper limits) for this mineral $(2500 \mathrm{mg} / \mathrm{d})$.

In contrast to the contribution of calcium in the basal diet, a deficient iodine supply was observed. Vitti et al. ${ }^{(34)}$ pointed out that most European countries are still characterized by mild-to-moderate iodine deficiency. Iodine RI are $110 \mu \mathrm{g} / \mathrm{d}$ for women and $140 \mu \mathrm{g} / \mathrm{d}$ for men. Although in the basal diet a mean intake value of $128 \mu \mathrm{g} / \mathrm{d}$ for the $28 \mathrm{~d}$ was observed, it has to be noted that the median was $107 \mu \mathrm{g} / \mathrm{d}$. Only in $25 \%$ of days for men and in $46 \%$ for women did the basal diet cover the daily recommended values. The maximum iodine level $(366 \cdot 2 \mu \mathrm{g} / \mathrm{d})$ was due to the presence of red mullet (Mullus sp.) in the menu. Hake, salmon, mackerel and tuna also contributed to adequate iodine intakes on other days of the dietary plan. Effectively, the presence of fish in the diets allowed to achieve the mean dietary recommended iodine intake considering the $28 \mathrm{~d}$ plan. The use of iodized table salt instead of common salt (diet 6) allowed reaching the RI of iodine every day, for both men and women. According to WHO, the current salt intake nowadays in Spain is around $11 \mathrm{~g} / \mathrm{d}$. If iodized table salt was provided at this level, no iodine deficiency would be observed, reaching intakes of around $216 \mu \mathrm{g} / \mathrm{d}$. Considering that the recommended salt intake is established at $5 \mathrm{~g} / \mathrm{d}$, iodine deficiency in that case would also be significantly reduced (diet 5) with the recommendations covered for women every day and in $71 \%$ of the days for men $($ mean value $=166 \mu \mathrm{g} / \mathrm{d})$. Vitti et al. ${ }^{(34)}$ showed that the strategy of salt iodization is very cheap, taking into account the beneficial impact of a correct iodine intake on health. When the developed diet substituted the use of daily bread $(180 \mathrm{~g} / \mathrm{d})$ made with iodized salt (diet 7) instead of common salt, the results were even more favourable, with a mean intake of iodine of around $278 \mu \mathrm{g} / \mathrm{d}$, which meant $199 \%$ and $253 \%$ of the RI for men and women, respectively. This fact let us to conclude that the development of new products made with iodized salt could be a very easy and efficient technological strategy to decrease iodine deficiency.

With regard to fat-soluble vitamins, the mean values observed for the basal diets reached the RI for vitamins A (men and women) and D. In the case of vitamin A, the RI for men was higher than for women, and the median for the percentage of RI was $97 \cdot 8 \%$, indicating that on a significant number of days the intake of vitamin A for men did not reach $100 \%$ of the RI (the 25 th percentile was $69.4 \%$ of RI; Table 4). The supply of vitamin D showed a high dispersion (SD), with a median of around half of the RI $(58 \cdot 1 \%)$. The worst situation was found for vitamin $\mathrm{E}$, which showed a mean and a median supply of $8 \mathrm{mg} / \mathrm{d}$, with $12 \mathrm{mg} / \mathrm{d}$ being its RI. This amount was covered only in $4 \%$ of the days. In fact, the value found for the 75 th percentile was only $9.3 \mathrm{mg} / \mathrm{d}$. These findings were likely due to the strict control of the fat content in the designed diets. In a study developed in Spain, it was found that the consumption of vitamin $\mathrm{A}$ is $800.63 \mu \mathrm{g} / \mathrm{d}^{(35)}$, and in a previous one the consumption was found to be $686 \mu \mathrm{g} / \mathrm{d}$ for men and $665 \mu \mathrm{g} / \mathrm{d}$ for women ${ }^{(36)}$. Moreover, vitamin A deficiency may be a cause of anaemia, although further study is needed to characterize both the pathogenesis and public health importance of this pathology ${ }^{(37)}$.

In Spain, the eVe Study ${ }^{(36)}$ provided data confirming the possible deficiency of vitamins $\mathrm{D}$ and $\mathrm{E}$ with mean intakes for men and women under the RI (vitamin D, men $2.42 \mu \mathrm{g} / \mathrm{d}$ and women $1.96 \mu \mathrm{g} / \mathrm{d}$; vitamin E, men $9.1 \mathrm{mg} / \mathrm{d}$, women $8.3 \mathrm{mg} / \mathrm{d}$ ). Furthermore, Sebastian et al. ${ }^{(38)}$ carried out a study in older adults, concluding that the use of vitamin/mineral supplements had a positive influence on nutrient adequacy in men and women aged $\geq 51$ years.

When vitamin A-enriched dairy products and margarine were used as substitutes of conventional foods (diet 8), the mentioned insufficiencies decreased significantly, increasing the number of days on which these RI were covered, achieving a median value of $1426 \mu \mathrm{g} / \mathrm{d}$. In fact, the 25 th percentile already covered the RI for both men and women. The UL for this vitamin was established at $3000 \mu \mathrm{g} / \mathrm{d}$. This value was reached only once during the $28 \mathrm{~d}$ dietary plan $(3341 \cdot 5 \mu \mathrm{g} / \mathrm{d})$, where spinach and carrots contributed significantly to vitamin A intake. As the 75 th percentile showed a value of $1724.9 \mu \mathrm{g} / \mathrm{d}$, it 
could be concluded that no problems of excessive intake were detected.

For vitamin D (diet 9), the supply was also higher than the RI, with a mean of $10 \mu \mathrm{g} / \mathrm{d}$, which was twice the RI but far from the UL $(50 \mu \mathrm{g})$. The enriched diets showed a median value of $6.7 \mu \mathrm{g} / \mathrm{d}$, covering the RI, which was an interesting improvement compared to the basal diet. However, probably the most relevant change was for vitamin $\mathrm{E}$, where the enriched foods allowed reaching a mean intake value of $15 \mathrm{mg} / \mathrm{d}$, with the 25 th percentile already showing a supply of $12.5 \mathrm{mg} / \mathrm{d}$, covering the RI for this vitamin.

Finally, we analysed the condition of $n$ - 3 fatty acids. As observed for vitamin $\mathrm{E}$, the mean contribution of $n-3$ fatty acids was insufficient to cover the dietary recommendations $(1 \cdot 3 \mathrm{~g} / \mathrm{d})$, nor did the median value cover the RI. Specifically, the basal diet covered the daily requirements only on $25 \%$ of the days (Table 4). According to SanchezVillegas et $a l^{(39)}$ the $n-3$ mean intake of the Spanish population is $0.99 \mathrm{~g} / \mathrm{d}$, a value that does not reach the RI for these fatty acids.

The inclusion of enriched margarine, butter, milk and biscuits (diet 11) contributed to improving the intake of $n$-3, increasing the mean supply from $1 \cdot 1 \mathrm{~g} / \mathrm{d}$ to $1 \cdot 4 \mathrm{~g} / \mathrm{d}$ (Table 3 ) and the number of days reaching the RI from $25 \%$ to $43 \%$ (Table 4). However, only the substitution of milk by soya drink, margarine, butter and biscuits (diet 12) was able to reach the RI on most of the days (93\%; Table 4), obtaining a mean intake of $1.9 \mathrm{~g} / \mathrm{d}$ and with a median of $1.8 \mathrm{~g} / \mathrm{d}$ (Table 3). Besides the increment in the supply of $n-3$ fatty acids achieved with diets 11 and 12, a decrease in the $n-6: n-3$ ratio (from $10 \cdot 4$ in the basal diet to $7 \cdot 6$ in the modified diets) was observed, which is also a beneficial effect. The $n-6: n-3$ ratio in occidental countries is $15^{(40)}$, the recommended values being about $4-5^{(40,41)}$.

The use of soya drink instead of milk as a source of $n-3$ fatty acids (diet 12) did not affect the fibre, energy or protein content of the diet. However, the supply of calcium, although quantitatively similar in this diet to that in the basal diet, showed a different bioavailability depending on the salt used for supplying calcium in this product ${ }^{(42,43)}$.

\section{Conclusion}

The analysed basal diet designed taking into account established guidelines showed deficiencies in iodine, vitamin $\mathrm{E}$ and $n-3$ fatty acids. However, no problems were found with regard to fibre and calcium. The substitution of conventional foods by enriched foods could increase the supply of all the studied compounds, helping to significantly decrease nutritional deficiencies.

\section{Acknowledgements}

The present study was supported by the 'Programa Consolider-Ingenio 2010 CARNISENUSA CSD2007-00016' and the 'Proyecto AGL2008-01099/ALI' (Ministerio de Ciencia e Innovación). The material in this manuscript has not been submitted to any journal, and to the best of the authors' knowledge contains no material previously published or written by another person. The authors have no conflicts of interest. I.B. contributed to the calibration of diets, data processing and first draft elaboration; M.C., A.R.d.1.H. and S.S. contributed to the design of basal diets; A.J.M. contributed to the data processing and editing; I.A. was the project leader and contributed to the experimental design and writing of the manuscript; D.A. contributed to the experimental design, statistical assessment and writing of the manuscript. Master Europeo en Alimentación, Metabolismo y Nutrición (University of Navarra) is acknowledged.

\section{References}

1. ILSI Europe Concise Monograph Series (2002) Concepts of functional foods. http://www.ilsi.org/Europe/Publications/ C2002Con_Food.pdf

2. Milner JA (2002) Functional foods and health: a US perspective. Br J Nutr 88, Suppl. 2, S151-S158.

3. Marlett JA, McBurney MI \& Slavin JL (2002) Position of the American Dietetic Association: health implications of dietary fiber. J Am Diet Assoc 102, 993-1000.

4. Castro IS, Barroso LP \& Sinnecker P (2005) Functional foods for coronary heart disease risk reduction: a metaanalysis using a multivariate approach. Am J Clin Nutr 82, $32-40$.

5. World Health Organization (2007) Iodine Deficiency in Europe: A Continuing Public Health Problem. Geneva: WHO.

6. Weaver CM (2003) Calcio. In Conocimientos Actuales Sobre Nutrición, 8th ed., pp. 297-305 [BA Bowman and RM Russell, editors]. Washington, DC: Organización Panamericana de la Salud y el Instituto Internacional de Ciencias de la Salud.

7. Zittermann A (2003) Vitamin D in preventive medicine: are we ignoring the evidence? Br J Nutr 89, 552-572.

8. Yoshikawa T (2009) Food factors for health promotion. Forum Nutr Basel, Karger 61, 55-63.

9. Stampfer MJ, Hennekens CH, Manson JE et al. (1993) Vitamin $\mathrm{E}$ consumption and the risk of coronary disease in women. $N$ Engl J Med 328, 1444-1449.

10. Rimm EB, Stampfer MJ, Ascherio A et al. (2002) Vitamin E consumption and the risk of coronary heart disease in men. $N$ Engl J Med 328, 1450-1456.

11. Simopoulos AP, Leaf A \& Salem N Jr (2000) Workshop statement on the essentiality of and recommended dietary intakes for omega- 6 and omega- 3 fatty acids. Prostaglandins Leukot Essent Fatty Acids 63, 119-121.

12. European Commission (2006) Regulation (EC) No 1924/ 2006 of the European Parliament and of the Council of 20 December 2006 on nutrition and health claims made on foods. Official Journal of the European Union $\mathbf{L ( 4 0 4 ) , ~}$ 9-25.

13. European Commission (2010) Regulation (EU) No 116/2010 of 9 February 2010 amending Regulation (EC) No 1924/2006 of the European Parliament and of the Council with regard to the list of nutrition claims. Official Journal of the European Union L(37), 16-18.

14. Cuervo M \& Ruiz de las Heras A (eds) (2004) Dieta basal. In Alimentación Hospitalaria. 2. Dietas Hospitalarias, pp. 2-73. Madrid: Ediciones Díaz de Santos. 
15. BOE (1983) Real Decreto 1424/1983, de 27 de Abril de 1983, por el que se aprueba la Reglamentación TécnicoSanitaria para la obtención, circulación y venta de sal y salmueras comestibles. BOE 130, 15261-15264.

16. Moreiras O, Carbajal A, Cabrera L et al. (2009) Tablas de Composición de Alimentos, 13th ed. Madrid: Pirámide.

17. Aranceta J, Pérez C, Serra L et al. (2007) Dieta y riesgo cardiovascular en España: Estudio DORICA (III). In Dieta y Riesgo Cardiovascular. Estudio DORICA II, pp. 121-162 [J Aranceta, M Foz, B Gil et al., editors]. Madrid: Editorial Médica Panamericana.

18. Schoppen S, Carbajal A, Pérez-Granados AM et al. (2005) Food, energy and macronutrient intake of postmenopausal women from a menopause program. Nutr Hosp 20, 101-109.

19. García L, López-Sobder AM, Aparicio A et al. (2005) Diferencias en la ingesta de nutrientes en escolares madrileños en función de su consumo de fruta. Nutr Hosp 20, 168-169.

20. Castetbon K, Vernay M, Malon A et al. (2009) Dietary intake, physical activity and nutritional status in adults: the French nutrition and health survey (ENNS, 2006-2007). Br J Nutr 102, 733-743.

21. Alonso A, Beunza JJ, Bes-Rastrollo M et al. (2006) Vegetable protein and fiber from cereal are inversely associated with the risk of hypertension in a Spanish cohort. Arch Med Res 37, 778-786.

22. Gómez C, Rosado JA \& Pérez A (2008) Recomendaciones de ingesta de fibra dietética. In Libro Blanco de la Fibra Dietética, pp. 57-65. Granda-Siero: Corporación Alimentaria Peñasanta SA.

23. Livesey G (2001) Tolerance of low-digestible carbohydrates: a general view. Br J Nutr 85, S5-S16.

24. Escudero E \& González P (2006) La fibra dietética. Nutr Hosp 21, 61-72.

25. National Institutes of Health Conseusus Statement (1994) Optimal Calcium Intake. Bethesda, MD: National Institutes of Health.

26. Heaney RP (2000) Calcium, dairy products and osteoporosis. J Am Coll Nutr 19, 2 Suppl., 83S-99S.

27. World Health Organization (2009) Calcium and Magnesium in Drinking-Water. Public Health Significance. Geneva: WHO.

28. Alonso A, Beunza JJ, Delgado-Rodriguez M et al. (2005) Low-fat dairy consumption and reduced risk of hypertension: the Seguimiento Universidad de Navarra (SUN) cohort. Am J Clin Nutr 82, 972-979.

29. Oliveras MJ, Nieto P, Agudo E et al. (2006) Evaluación nutricional de una población universitaria. Nutr Hosp 21, 179-193.
30. Villarino A, García-Linares MC, García-Fernandez MC et al. (2003) Evaluación dietética y parámetros bioquímicos de minerales en un colectivo de ancianos de la provincia de León (España). Nutr Hosp 18, 39-45.

31. Joyce T, Hannon EM, Kiely M et al. (2006) Analysis of the impact of fortified food consumption on overall dietary quality in Irish adults. Br J Nutr 101, 431-439.

32. World Cancer Research Foundation (2007) Food, Nutrition, Physical Activity, and the Prevention of Cancer: A Global Perspective, 2nd ed. Washington, DC: American Institute for Cancer Research.

33. Abrans SA \& Atkinson SA (2003) Calcium, magnesium, phosphorus and fortified complementary foods. $J$ Nutr 133, 2994S-2999S.

34. Vitti P, Rago T, Aghini-Lombardi $\mathrm{F}$ et al. (2001) Iodine deficiency disorders in Europe. Public Health Nutr 4, 529-535.

35. Morales O, Ochoa JJ, López-Frías M et al. (2007) Ingesta de vitamina A en la población adulta de la Comunidad Autónoma Andaluza. Nutr Hosp 22, 108-111.

36. Aranceta J, Serra L, Pérez C et al. (2001) Las vitaminas en la alimentación de los españoles. Estudio eVe. Análisis en la población general. In Las vitaminas en la alimentación de los españoles. Estudio eVe, pp. 49-150 [J Aranceta, L Serra, R Ortega, et al., editors]. Madrid: Editorial Panamericana.

37. Semba RD \& Bloem MW (2002) The anemia of vitamin A deficiency: epidemiology and pathogenesis. Eur J Clin Nutr 56, 271-281.

38. Sebastian RS, Cleveland LE, Goldman JD et al. (2007) Older adults who use vitamin/mineral supplements differ from nonusers in nutrient intake adequacy and dietary attitudes. J Am Diet Assoc 107, 1322-1332.

39. Sanchez-Villegas A, Henriquez P, Figueiras A et al. (2007) Long chain omega-3 fatty acids intake, fish consumption and mental disorders in the SUN cohort study. Eur J Nutr 46, 337-346.

40. Wood JD, Richardson RI, Nute GR et al. (2003) Effects of fatty acids on meat quality: a review. Meat Sci 66, 21-32.

41. Kris-Etherton PM, Harris WS \& Appel LJ (2003) Omega-3 fatty acids and cardiovascular disease: new recommendations from the American Heart Association. Arterioscler Thromb 23, 151-152.

42. Heaney RP, Dowen MS, Rafferty K et al. (2007) Bioavailability of the calcium in fortified soy imitation milk, with some observations on method. Am J Clin Nutr $\mathbf{7 1}$, 1166-1169.

43. Zhao Y, Martin BR \& Waver CM (2005) Calcium bioavailability of calcium carbonate fortified soymilk is equivalent to cow's milk in young women. J Nutr 135, 2379-2382. 